$\begin{array}{ll}\text { Volume } & : 04 \\ \text { Nomor } & : 02 \\ \text { Bulan } & : \text { Mei } \\ \text { Tahun } & : 2018 \\ \text { http } & : / / \text { jurnal.pps.ung.ac.id/index.php/AKSARA/index }\end{array}$

\title{
Pelaksanaan Bimbingan Berkelanjutan dalam Upaya Meningkatkan Kompetensi Guru Menyusun Rencana Pelaksanaan Pembelajaran Di SDN 01 Popayato
}

\author{
Imran Panigoro \\ SDN 01 Popayato Kabupaten Pohuwato \\ imranpanigoro@gmail.com
}

\begin{abstract}
Abstrak
Penelitian ini bertujuan untuk meningkatkan kopetensi guru dalam menyusun rencana pelaksanaan pembelajaran melalui bimbingan berkelanjutan di SDN 01 Popayato Tahun Pelajaran 2017/2018. Metode penelitian yang digunakan adalah metode Penelitian Tindakan kelas (PTK) dalam dua siklus, dan masing-masing siklus terdiri dari empat tahapan, yakni tahap perencanaan, tahap pelaksanan, tahap pengamatan dan Refleksi. Hasil penelitian membuktikan bahwa Bimbingan berkelanjutan dapat meningkatkan kompetensi guru dalam menyusun RPP. Hal itu dapat dibuktikan dari hasil observasi /pengamatan yang memperlihatkan bahwa terjadi peningkatan kompetensi guru dalam menyusun RPP dari siklus ke siklus. Pada siklus I nilai rata-rata komponen RPP 70,17\%, pada siklus II nilai rata-rata komponen RPP 86,08\%, terjadi peningkatan 15,91\%.
\end{abstract}

Kata Kunci: Kompetensi Guru, RPP, Bimbingan Berkelanjutan

\section{Pendahuluan}

Pendidikan adalah proses merubah manusia menjadi lebih baik, lebih mahir dan lebih terampil. Untuk mencapai tujuan tersebut tentunya dibutuhkan strategi yang disebut dengan strategi pembelajaran. Dalam strategi pembelajaran terkandung tiga hal pokok yakni perencanaan, pelaksanaan dan evaluasi.

Perencanaan pembelajaran merupakan langkah yang sangat penting sebelum pelaksanaan pembelajaran. Perencanaan yang matang diperlukan supaya pelaksanaan pembelajaran berjalan secara efektif. Perencanaan pembelajaran dituangkan ke dalam Rencana Pelaksanaan Pembelajaran (RPP) atau beberapa istilah lain seperti desain pembelajaran, skenario pembelajaran. RPP memuat KD, indikator yang akan dicapai, materi yang akan dipelajari, metode pembelajaran, langkah pembelajaran, media pembelajaran, dan sumber belajar serta penilaian

Perencanaan pembelajaran merupakan langkah yang sangat penting sebelum pelaksanaan pembelajaran. Perencanaan yang matang diperlukan supaya pelaksanaan pembelajaran berjalan secara efektif. Perencanaan pembelajaran dituangkan ke dalam Rencana Pelaksanaan Pembelajaran (RPP) atau beberapa istilah lain seperti desain pembelajaran, skenario pembelajaran. RPP memuat KD, indikator yang akan dicapai, materi yang akan dipelajari, metode pembelajaran, langkah pembelajaran, media pembelajaran, dan sumber belajar serta penilaian.

Silabus dan RPP dikembangkan oleh guru pada satuan pendidikan . Guru pada satuan pendidikan berkewajiban menyusun Silabus dan RPP secara lengkap dan sistematis agar pembelajaran berlangsung secara interaktif, inspiratif, 


$\begin{array}{ll}\text { Volume } & : 04 \\ \text { Nomor } & : 02 \\ \text { Bulan } & : \text { Mei } \\ \text { Tahun } & : 2018 \\ \text { http } & : / / \text { jurnal.pps.ung.ac.id/index.php/AKSARA/index }\end{array}$

menyenangkan, menantang, memotivasi peserta didik untuk berpartisipasi aktif, serta memberikan ruang yang cukup bagi prakarsa, kreativitas, dan kemandirian sesuai dengan bakat, minat dan perkembangan fisik serta psikologis peserta didik.

Seorang guru harus mampu berperan sebagai desainer (perencana), implementor (pelaksana), dan evaluator (penilai) kegiatan pembelajaran. Guru merupakan faktor yang paling dominan karena di tangan gurulah keberhasilan pembelajaran dapat dicapai. Kualitas mengajar guru secara langsung maupun tidak langsung dapat mempengaruhi kualitas pembelajaran pada umumnya. Seorang guru dikatakan profesional apabila (1) serius melaksanakan tugas profesinya, (2) bangga dengan tugas profesinya, ( 3) selalu menjaga dan berupaya meningkatkan kompetensinya, (4) bekerja dengan sungguh tanpa harus diawasi, (5) menjaga nama baik profesinya, (6) bersyukur atas imbalan yang diperoleh dari profesinya.

Diantara kewajiban sebagai guru yang harus dikerjakan untuk melayani peserta dIdik dalam setiap awal semester yaitu merencanakan pembelajaran, tidak sedikit guru dalam merencanakan pembelajaran ini belum memahami secara utuh, sehingga dalam menyiapkan atau menyusun secara tertulis perencanaan ini belum sempurna dan bahkan ada yang tidak menyusun. Tentu hal ini sangat terkait dengan kesadaran kemauan dan kemampuan diri pribadi guru.

Dengan melihat pentingnya penyusunan perencanaan pembelajaran ini, guru semestinya tidak mengajar tanpa adanya rencana. Namun sayang perencanaan pembelajaran yang mestinya dapat diukur oleh kepala sekolah ini, tidak dapat diukur oleh kepala sekolah karena hanya direncanakan dalam pikiran sang guru saja. Masih banyak guru yang tidak bisa memperlihatkan RPP yang dibuat dengan alasan ketinggalan di rumah dan bagi guru yang sudah membuat RPP masih ditemukan adanya guru yang belum melengkapi komponen tujuan pembelajaran dan penilaian (soal, skor dan kunci jawaban), serta langkah-langkah kegiatan pembelajarannya masih dangkal. Soal, skor, dan kunci jawaban merupakan satu kesatuan yang tidak dapat dipisahkan. Pada komponen penilaian (penskoran dan kunci jawaban) sebagian besar guru tidak lengkap membuatnya dengan alasan sudah tahu dan ada di kepala. Sedangkan pada komponen tujuan pembelajaran, materi ajar, metode pembelajaran, dan sumber belajar sebagian besar guru sudah membuatnya.

Berdasarkan uraian di atas penulis mengadakan penelitian tindakan sekolah dengan judul: "Pelaksanaan Bimbingan Berkelanjutan Dalam Upaya Meningkatkan Kompetensi Guru Menyusun Rencana Pelaksanaan Pembelajaran Di Sdn 01 Popayato"

\section{Kajian Pustaka}

\section{Standar Kompetensi Guru}

Nurhadi (2004:15) menyatakan bahwa kompetensi merupakan pengetahuan, keterampilan, dan nilai-nilai dasar yang direfleksikan dalam kebiasaan berpikir dan bertindak. Selanjutnya menurut para ahli pendidikan McAshan (dalam Nurhadi 2004:16) menyatakan bahwa kompetensi diartikan sebagai pengetahuan, keterampilan, dan kemampuan yang dikuasai seseorang sebagai pengetahuan, keterampilan, dan kemampuan yang dikuasai seseorang yang 


$\begin{array}{ll}\text { Volume } & : 04 \\ \text { Nomor } & : 02 \\ \text { Bulan } & : \text { Mei } \\ \text { Tahun } & : 2018 \\ \text { http } & : / / \text { jurnal.pps.ung.ac.id/index.php/AKSARA/index }\end{array}$

telah menjadi bagian dari dirinya, sehingga dapat melakukan perilaku-perilaku koqnitif, afektif, dan psikomotor dengan sebaik-baiknya.

Depdiknas (2004:4) kompetensi diartikan sebagai pengetahuan, keterampilan, dan nilai-nilai dasar yang direfleksikan dalam kebiasaan berpikir dan bertindak. Secara sederhana kompetensi diartikan seperangkat kemampuan yang meliputi pengetahuan, sikap, nilai dan keterampilan yang harus dikuasai dan dimiliki seseorang dalam rangka melaksanakan tugas pokok, fungsi dan tanggung jawab pekerjaan dan/atau jabatan yang disandangnya (Nana Sudjana 2009:1). Sedangkan Abdurrahman Mas'ud (dalam Suparlan 2005:99) menyebutkan tiga kompetensi dasar yang harus dimiliki guru, yakni: (1) menguasai materi atau bahan ajar, (2) antusiasme, dan (3) penuh kasih sayang (loving) dalam mengajar dan mendidik.

Undang-Undang Guru dan Dosan No.14 Tahun 2005 Pasal 8 menyatakan, "guru wajib memiliki kualifikasi akademik, kompetensi, sertifikat pendidik, sehat jasmani dan rohani, serta memiliki kemampuan untuk mewujudkan tujuan pendidikan nasional." Dari rumusan di atas jelas disebutkan pemilikan kompetensi oleh setiap guru merupakan syarat yang mutlak harus dipenuhi oleh guru. Dengan demikian, kompetensi yang dimiliki oleh setiap guru akan menunjukkan kualitas guru yang sebenarnya. Selanjutnya Pasal 10 menyebutkan empat kompetensi yang harus dimiliki oleh guru yakni (1) kompetensi pedagogik, (2) kompetensi kepribadian, (3) kompetensi sosial, dan (4) kompetensi profesional.Kompetensi tersebut akan terwujud dalam bentuk penguasaan pengetahuan, keterampilan, maupun sikap profesional dalam menjalankan fungsi sebagai guru.

Berdasarkan beberapa definisi di atas dapat disimpulkan standar Kompetensi guru adalah suatu pernyataan tentang kriteria yang dipersyaratkan, ditetapkan dalam bentuk penguasaan perangkat kemampuan yang meliputi pengetahuan, sikap, nilai dan keterampilan bagi seorang tenaga kependidikan sehingga layak disebut kompeten. Standar kompetensi guru dipilah ke dalam tiga komponen yang kait- mengait, yakni: 1) pengelolaan pembelajaran, 2) pengembangan profesi, dan 3) penguasaan akademik. Komponen pertama terdiri atas empat kompetensi, komponen kedua memiliki satu kompetensi, dan komponen ketiga memiliki dua kompetensi. Dengan demikian, ketiga komponen tersebut secara keseluruhan meliputi tujuh kompetensi dasar, yaitu: penyusunan rencana pembelajaran, 2) pelaksanaan interaksi belajar mengajar, 3) penilaian prestasi belajar peserta didik, 4) pelaksanaan tindak lanjut hasil penilaian prestasi belajar peserta didik, 5) pengembangan profesi, 6) pemahaman wawasan kependidikan, dan 7) penguasaan bahan kajian akademik (sesuai dengan mata pelajaran yang diajarkan).

Depdiknas (2004: 4) menyatakan tujuan adanya Standar Kompetensi Guru adalah sebagai jaminan dikuasainya tingkat kompetensi minimal oleh guru sehingga yang bersangkutan dapat melakukan tugasnya secara profesional, dapat dibina secara efektif dan efisien serta dapat melayani pihak yang berkepentingan terhadap proses pembelajaran, dengan sebaik-baiknya sesuai bidang tugasnya. Adapun manfaat disusunnya standar kompetensi guru adalah sebagai acuan pelaksanaan uji kompetensi, penyelenggaraan diklat, dan pembinaan, maupun 


$\begin{array}{ll}\text { Volume } & : 04 \\ \text { Nomor } & : 02 \\ \text { Bulan } & : \text { Mei } \\ \text { Tahun } & : 2018 \\ \text { http } & : \text { //ejurnal.pps.ung.ac.id/index.php/AKSARA/index }\end{array}$

acuan bagi pihak yang berkepentingan terhadap kompetensi guru untuk melakukan evaluasi, pengembangan bahan ajar dan sebagainya bagi tenaga kependidikan.

\section{Rencana Pelaksanaan Pembelajaran}

Philip Combs (dalam Kurniawati, 2009:66) menyatakan bahwa perencanaan program pembelajaran merupakan suatu penetapan yang memuat komponenkomponen pembelajaran secara sistematis. Analisis sistematis merupakan proses perkembangan pendidikan yang akan mencapai tujuan pendidikan agar lebih efektif dan efisien disusun secara logis, rasional, sesuai dengan kebutuhan siswa, sekolah, dan daerah (masyarakat). Perencanaan program pembelajaran adalah hasil pemikiran, berupa keputusan yang akan dilaksanakan. Selanjutnya Oemar Hakim (dalam Kurniawati 2009:74) menyatakan, "bahwa perencanaan program pembelajaran pada hakekatnya merupakan perencanaan program jangka pendek untuk memperkirakan suatu proyeksi tentang sesuatu yang akan dilakukan dalam kegiatan pembelajaran".

Permendiknas No. 41 Tahun 2007 menyatakan, "Rencana Pelaksanaan Pembelajaran (RPP) adalah rencana yang menggambarkan prosedur dan pengorganisasian pembelajaran untuk mencapai satu kompetensi dasar yang ditetapkan dalam standar isi dan telah dijabarkan dalam silabus."

Berdasarkan pendapat di atas dapat disimpulkan bahwa perencanaan pembelajaran adalah suatu upaya menyusun perencanaan pembelajaran yang akan dilaksanakan dalam kegiatan pembelajaran untuk mencapai tujuan yang telah ditetapkan dalam kurikulum sesuai dengan kebutuhan siswa, sekolah, dan daerah.

Menurut Permendiknas No. 41 Tahun 2007, komponen RPP terdiri dari a). identitas mata pelajaran, (b) standar kompetensi, (c) kompetensi dasar, (d) indikator pencapaian kompetensi, (e) tujuan pembelajaran, (f) materi ajar, (g) alokasi waktu , (h) metode pembelajaran, (i) kegiatan pembelajaran meliputi: pendahuluan, inti, penutup. (j) sumber belajar, (k) penilaian hasil belajar meliputi: soal, skor dan kunci jawaban. Sedangkan berdasarkan Peraturan Pemerintah Republik Indonesia No. 19 (2005 pasal 20) menyatakan bahwa, "RPP minimal memuat sekurang-kurangnya lima komponen yang meliputi: (1) tujuan pembelajaran, (2) materi ajar, (3) metode pengajaran, (4) sumber belajar, dan (5) penilaian hasil belajar."

Permendiknas No. 41 Tahun 2007 menyatakan dalam menyusun rencana pelaksanaan pembelajaran harus memperhatikan prinsip-prinsip sebagai berikut: a) memperhatikan perbedaan individu peserta didik, b) mendorong partisipasi aktif peserta didik, c) mengembangkan budaya membaca dan menulis, d) memberikan umpan balik dan tindak lanjut, e) keterkaitan dan keterpaduan, f) menerapkan teknologi informasi dan komunikasi RPP .

Langkah-langkah menyusun RPP adalah a) mengisi kolom identitas, b) Menentukan alokasi waktu yang dibutuhkan untuk pertemuan yang telah ditetapkan, c) Menentukan SK, KD, dan indikator yang akan digunakan yang terdapat pada silabus yang telah disusun, d) Merumuskan tujuan pembelajaran berdasarkan SK, KD dan indikator yang telah ditentukan, e) mengidentifikasi materi ajar berdasarkan materi pokok/pembelajaran yang terdapat dalam silabus, materi ajar merupakan uraian dari materi pokok/pembelajaran, f) menentukan 


$\begin{array}{ll}\text { Volume } & : 04 \\ \text { Nomor } & : 02 \\ \text { Bulan } & : \text { Mei } \\ \text { Tahun } & : 2018 \\ \text { http } & : / / \text { jurnal.pps.ung.ac.id/index.php/AKSARA/index }\end{array}$

metode pembelajaran yang akan digunakan, g) merumuskan langkah-langkah yang terdiri dari kegiatan awal, inti dan akhir. h) menentukan alat/bahan/sumber belajar yang digunakan, i) menyusun kriteria penilaian, lembar pengamatan, contoh soal, teknik penskoran dan kunci jawaban.

Dalam penyusunan RPP perlu memperhatikan hal sebagai berikut: (a) RPP disusun untuk setiap KD yang dapat dilaksanakan dalam satu kali pertemuan atau lebih, b) tujuan pembelajaran menggambarkan proses dan hasil belajar yang harus di capai oleh peserta didik sesuai dengan kompetenrsi dasar, c) tujuan pembelajaran dapat mencakupi sejumlah indikator, atau satu tujuan pembelajaran untuk beberapa indikator, yang penting tujuan pembelajaran harus mengacu pada pencapaian indikator, d) Kegiatan pembelajaran (langkah-langkah pembelajaran) dibuat setiap pertemuan, bila dalam satu RPP terdapat 3 kali pertemuan, maka dalam RPP tersebut terdapat 3 langkah pembelajaran, e). Bila terdapat lebih dari satu pertemuan untuk indikator yang sama, tidak perlu dibuatkan langkah kegiatan yang lengkap untuk setiap pertemuannya.

\section{Bimbingan Berkelanjutan}

Menurut Frank W. Miller dalam Willis (2010:13) menyatakan bahwa bimbingan merupakan proses bantuan terhadap individu untuk mencapai pemahaman diri dan pengarahan diri yang dibutuhkan bagi penyesuaian diri secara baik dan maksimum disekolah, keluarga dan masyarakat. Sedangkan menurut Sukardi (1988:1) menyatakan bahwa bimbingan adalah bantuan yang diberikan kepada individu dalam menentukan pilihan dan mengadakan penyesuaian secara logis dan Nalar.

Menurut Arthur J. Jones dalam Sukardi (1988 : 8) bimbingan adalah bantuan yang diberikan oleh seseorang kepada orang lainnya dalam menetapkan pilihan dan penyesuaian diri, serta didalam memecahkan masalah - masalah. Sedangkan menurut Frank Parson dalam Salahudin (2010: 13), pengertian bimbingan adalah bantuan yang diberikan kepada individu untuk memilih, mempersiapkan diri dan memangku suatu jabatan, serta mendapat kemajuan dalam jabatan yang dipilihnya Dan menurut Prayitno dan Erman Amti dalam Salahudin (2010: 14) bimbingan adalah: proses pemberian bantuan yang di lakukan oleh orang yang ahli kepada seseorang atau beberapa orang individu, baik anak-anak, remaja, maupun dewasa.

Menurut Walgito (1986:10) bimbingan adalah bantuan atau pertolongan yang di berikan kepada individu atau sekumpulan individu-individu dalam menghindari atau mengatasi kesulitan-kesulitan di dalam kehidupannya, agar indivisu atau sekumpulan individu itu dapat mencapai kesejahteraan hidupnya. Sedangkan menurut Winkel dalam Salahudin (2010: 14) bahwa pengertian bimbingan adalah sebagai berikut:

1.) Bimbingan adalah: usaha untuk melengkapi individu dengan pengetahuan, pengalaman, dan informasi tentang dirinya sendiri.

2.) Bimbingan adalah: cara untuk memberikan bantuan kepada individu untuk memahami dan mempergunakan secara efisien dan efektif segala kesempatan yang di miliki untuk perkembangan pribadinya 


$\begin{array}{ll}\text { Volume } & : 04 \\ \text { Nomor } & : 02 \\ \text { Bulan } & : \text { Mei } \\ \text { Tahun } & : 2018 \\ \text { http } & : \text { //ejurnal.pps.ung.ac.id/index.php/AKSARA/index }\end{array}$

Dari beberapa pengertian bimbingan di atas, dapat ditarik kesimpulan bahwa bimbingan adalah pemberian bantuan kepada individu secara berkelanjutan dan sistematis yang dilakukan oleh seorang ahli yang telah mendapat latihan khusus untuk itu,dimaksudkan agar individu dapat memahami dirinya, lingkungannya, serta dapat mengarahkan diri dan menyesuaikan diri dengan lingkungan untuk dapat mengembangkan potensi dirinya secara optimal untuk kesejahteraan dirinya dan kesejahteraan masyarakat. Menurut Redaksi Kamus Besar Bahasa Indonesia, Edisi Kedua, "berkelanjutan adalah berlangsung terus menerus, berkesinambungan."

Berdasarkan pengertian bimbingan dan berkelanjutan dapat ditarik suatu kesimpulan bahwa bimbingan berkelanjutan adalah pemberian bantuan yang diberikan seorang ahli kepada seseorang atau individu secara berkelanjutan berlangsung secara terus menerus untuk dapat mengembangkan potensi dirinya secara optimal dan mendapat kemajuan dalam bekerja.

\section{Metode Penelitian}

Penelitian Tindakan Sekolah (PTS) dilaksanakan di SDN 01 Popayato Kabuapten Pohuwato. Penilitian Tindakan Sekolah ini dilaksanakan pada semester I tahun pelajaran 2016/2017, adapun yang menjadi subjek penelitian tindakan sekolah ini adalah guru-guru di SDN 01 Popayato yang berjumlah 8 Guru.Teknik dalam penelitian ini adalah wawancara, observasi, dan diskusi sedangkan alat pengumpulan data dalam PTS ini adalah sebagai berikut: (a) Wawancara menggunakan panduan wawancara untuk mengetahui kemampuan awal yang dimiliki guru tentang Rencana Pelaksanaan Pembelajaran, (b) observasi menggunakan lembar observasi untuk mengetahui komponen RPP yang telah dibuat dan yang belum dibuat oleh guru, (c) diskusi dilakukan dengan maksud untuk sharing pendapat antara peneliti dengan guru

Penelitian ini berbentuk Penelitian Tindakan Sekolah (School Action Research), yaitu sebuah penelitian yang merupakan kerjasama antara peneliti dan guru, dalam meningkatkan kemampuan guru agar menjadi lebih baik dalam menyusun rencana pelaksanaan pembelajaran. Metode yang digunakan dalam penelitian ini adalah metode deskriptif, dengan menggunakan teknik persentase untuk melihat peningkatan yang terjadi dari siklus ke siklus

Prosedur penelitian ini mencakup tahap-tahap: (1) perencanaan, (2) pelaksanaan, (3) pengamatan, dan (4) refleksi. Keempat kegiatan tersebut saling terkait dan secara urut membentuk sebuah siklus. Penelitian Tindakan Sekolah merupakan penelitian yang bersiklus, artinya penelitian dilakukan secara berulang dan berkelanjutan sampai tujuan penelitian dapat tercapai. Penelitian Tindakan Sekolah dilaksanakan melalui dua siklus untuk melihat peningkatan kompetensi guru dalam menyusun Rencana Pelaksanaan Pembelajaran (RPP ) dengan teknik pengumpulan data dalam penelitian ini adalah wawancara, observasi, dan diskusi. Wawancara dipergunakan untuk mendapatkan data atau informasi tentang pemahaman guru terhadap RPP. Observasi dipergunakan untuk mengumpulkan data dan mengetahui kompetensi guru dalam menyusun Rencana Pelaksanaan Pembelajaran dengan lengkap. Sedangkan Diskusi dilakukan antara peneliti dengan guru 


$\begin{array}{ll}\text { Volume } & : 04 \\ \text { Nomor } & : 02 \\ \text { Bulan } & : \text { Mei } \\ \text { Tahun } & : 2018 \\ \text { http } & : / / \text { jurnal.pps.ung.ac.id/index.php/AKSARA/index }\end{array}$

\section{Hasil Penelitian dan Pembahasan}

Untuk memperoleh data awal tentang kompetensi guru dalam menyusun RPP (rencana pelaksanaan pembelajaran), peneliti melakukan pengamatan terhadap guru yang ada di SDN 01 Popayato Kabupaten Pohuwato. Pengamatan dilakukan untuk melakukan penilaian terhadap kompetensi guru dengan menggunakan pedoman penilaian atau observasi yang telah dirancang sebelumnya. Dari hasil wawancara terhadap delapan orang guru, peneliti memperoleh informasi bahwa masih banyak guru yang belum tahu kerangka penyusunan RPP, hanya sekolah yang memiliki dokumen standar proses (satu buah), hanya beberapa orang guru yang pernah mengikuti pelatihan pengembangan RPP, umumnya guru mengadopsi dan mengadaptasi RPP, kebanyakan guru tidak tahu dan tidak paham menyusun RPP secara lengkap, mereka setuju bahwa guru harus menggunakan RPP dalam melaksanakan proses pembelajaran yang dapat dijadikan acuan/pedoman dalam proses pembelajaran. Selain itu, kebanyakan guru belum tahu dengan komponenkomponen RPP secara lengkap.

Berdasarkan hasil observasi peneliti terhadap delapan RPP yang dibuat guru (khusus pada siklus I), diperoleh informasi/data bahwa masih ada guru yang tidak melengkapi RPP-nya dengan komponen dan sub-subkomponen RPP tertentu, misalnya komponen indikator dan penilaian hasil belajar (pedoman penskoran dan kunci jawaban). Rumusan kegiatan siswa pada komponen langkah-langkah kegiatan pembelajaran masih kurang tajam, interaktif, inspiratif, menantang, dan sistematis.

Tabel 1

Data awal Kompetensi Guru Dalam Menyusun RPP di SDN 01 Popayato

\begin{tabular}{|c|c|c|c|c|c|c|c|c|c|c|c|c|c|}
\hline \multirow{2}{*}{ No } & \multirow{2}{*}{ Nama } & \multicolumn{11}{|c|}{ Aspek yang Dinilai } & \multirow{2}{*}{ Jumlah } \\
\hline & & $\mathrm{A}$ & B & $\mathrm{C}$ & $\mathrm{D}$ & $\mathrm{E}$ & $\mathrm{F}$ & $\mathrm{G}$ & $\mathrm{H}$ & I & $\mathrm{J}$ & $\mathrm{K}$ & \\
\hline 1 & Maryam Onu, S.Pd & 4 & 4 & 3 & 4 & 3 & 3 & 2 & 2 & 2 & 2 & 2 & 31 \\
\hline 2 & Yowan Umar, S.Pd & 3 & 3 & 3 & 3 & 3 & 3 & 2 & 3 & 2 & 2 & 3 & 30 \\
\hline 3 & I Made Bawa, S.Pd & 4 & 3 & 2 & 2 & 3 & 3 & 3 & 2 & 2 & 2 & 1 & 27 \\
\hline 4 & $\begin{array}{l}\text { Sri Yiyin Otoluwa, } \\
\text { S.Pd }\end{array}$ & 4 & 2 & 3 & 3 & 2 & 2 & 1 & 1 & 1 & 2 & 1 & 22 \\
\hline 5 & Supratni & 3 & 2 & 2 & 2 & 3 & 1 & 2 & 3 & 3 & 2 & 2 & 25 \\
\hline 6 & Rita Godang & 2 & 2 & 1 & 2 & 2 & 3 & 3 & 2 & 2 & 1 & 2 & 22 \\
\hline 7 & Isnah H Rumampuk & 4 & 3 & 2 & 1 & 2 & 1 & 1 & 2 & 2 & 1 & 1 & 20 \\
\hline 8 & Ahrudin A Otoluwa & 3 & 2 & 2 & 2 & 2 & 2 & 1 & 1 & 1 & 2 & 1 & 19 \\
\hline \multicolumn{13}{|c|}{ Jumlah } & 196 \\
\hline \multicolumn{13}{|c|}{ persentase } & 55,68 \\
\hline
\end{tabular}

Keterangan :

$\mathrm{A}=$ Komponen identitas mata pelajaran

$\mathrm{B}=$ Komponen standar kompetensi 


$\begin{array}{ll}\text { Volume } & : 04 \\ \text { Nomor } & : 02 \\ \text { Bulan } & : \text { Mei } \\ \text { Tahun } & : 2018 \\ \text { http } & : / / \text { jurnal.pps.ung.ac.id/index.php/AKSARA/index }\end{array}$

$\mathrm{C}=$ Komponen kompotensi dasar

$\mathrm{D}=$ Komponen indikator

$\mathrm{E}=$ Komponen tujuan pembelajaran

$\mathrm{F}=$ Komponen alokasi waktu

$\mathrm{G}=$ Komponen materi ajar

$\mathrm{H}=$ Komponen metode pembelajaran

$\mathrm{I}=$ Komponen langkah - langkah kegaiatan pembelajaran

$\mathrm{J}=$ Komponen Sumber Belajar

$\mathrm{K}=$ Komponen Penilaian

Ketercapaian :

$85 \%-100 \%=$ sangat baik

$70 \%-84 \%=$ baik

$55 \%-69 \%=$ cukup

Dibawah 55\% = kurang

Berdasarkan tabel 4.1 di atas menunjukkan bahwa dari segi kualitas kompetensi guru di SDN 01 Popayato termasuk dalam kategori cukup baik. Hal ini dapat dilihat dari persentase yang diperoleh yaitu 55,68\%.

\section{Siklus I}

Siklus pertama terdiri dari empat tahap yakni:(a) Perencanaan ( Planning ) (1) Membuat lembar wawancara,(2) Membuat format/instrumen penilaian RPP,(3) Membuat format rekapitulasi hasil penyusunan RPP siklus I , (4) Membuat format rekapitulasi hasil penyusunan RPP siklus I (b) Pelaksanaan (Acting) : Peneliti memberikan bimbingan secara berkelanjutan berlangsung secara terus menerus untuk dapat mengembangkan potensi guru secara optimal dan mendapat kemajuan dalam menyusun RPP. (c) Observasi dilaksanakan terhadap delapan orang guru. Berdasarkan penilaian yang dilakukan diperoleh data mengenai kompetensi guru dalam menyusun RPP berikut ini:

Tabel 2

Data Kompetensi Guru Dalam Menyusun RPP di SDN 01 Popayato Siklus I

\begin{tabular}{|c|c|c|c|c|c|c|c|c|c|c|c|c|c|}
\hline \multirow{2}{*}{ No } & \multirow{2}{*}{ Nama } & \multicolumn{11}{|c|}{ Aspek yang Dinilai } & \multirow{2}{*}{ Jumlah } \\
\hline & & $\mathrm{A}$ & $\mathrm{B}$ & $\mathrm{C}$ & $\mathrm{D}$ & $\mathrm{E}$ & $\mathrm{F}$ & $\mathrm{G}$ & $\mathrm{H}$ & $\mathrm{I}$ & $\mathrm{J}$ & $\mathrm{K}$ & \\
\hline 1 & Maryam Onu, S.Pd & 4 & 4 & 3 & 4 & 3 & 3 & 3 & 3 & 3 & 3 & 2 & 35 \\
\hline 2 & Yowan Umar, S.Pd & 3 & 3 & 3 & 3 & 3 & 3 & 3 & 3 & 2 & 3 & 3 & 32 \\
\hline 3 & I Made Bawa, S.Pd & 4 & 4 & 3 & 3 & 3 & 3 & 2 & 2 & 3 & 3 & 3 & 33 \\
\hline 4 & $\begin{array}{l}\text { Sri Yiyin Otoluwa, } \\
\text { S.Pd }\end{array}$ & 4 & 3 & 3 & 3 & 3 & 2 & 2 & 3 & 3 & 3 & 2 & 31 \\
\hline 5 & Supratni & 3 & 3 & 3 & 3 & 3 & 2 & 2 & 2 & 2 & 3 & 2 & 28 \\
\hline 6 & Rita Godang & 2 & 4 & 3 & 4 & 3 & 3 & 2 & 2 & 2 & 3 & 3 & 31 \\
\hline 7 & Isnah H Rumampuk & 4 & 3 & 3 & 3 & 3 & 2 & 2 & 2 & 2 & 3 & 3 & 30 \\
\hline 8 & Ahrudin A Otoluwa & 3 & 2 & 3 & 3 & 3 & 2 & 2 & 2 & 2 & 3 & 2 & 27 \\
\hline \multicolumn{13}{|c|}{ Jumlah } & 247 \\
\hline \multicolumn{13}{|c|}{ persentase } & 70,17 \\
\hline
\end{tabular}




$\begin{array}{ll}\text { Volume } & : 04 \\ \text { Nomor } & : 02 \\ \text { Bulan } & : \text { Mei } \\ \text { Tahun } & : 2018 \\ \text { http } & : / / \text { jurnal.pps.ung.ac.id/index.php/AKSARA/index }\end{array}$

Keterangan :

$\mathrm{A}=$ Komponen identitas mata pelajaran

$\mathrm{B}=$ Komponen standar kompetensi

$\mathrm{C}=$ Komponen kompotensi dasar

$\mathrm{D}=$ Komponen indikator

$\mathrm{E}=$ Komponen tujuan pembelajaran

$\mathrm{F}=$ Komponen alokasi waktu

$\mathrm{G}=$ Komponen materi ajar

$\mathrm{H}=$ Komponen metode pembelajaran

$\mathrm{I}=$ Komponen langkah - langkah kegaiatan pembelajaran

$\mathrm{J}=$ Komponen Sumber Belajar

$\mathrm{K}=$ Komponen Penilaian

Ketercapaian :

$85 \%-100 \%=$ sangat baik

$70 \%-84 \%=$ baik

$55 \%-69 \%=$ cukup

Dibawah 55\% = kurang

Pada siklus I apabila dilihat dari segi kualitas kompetensi guru di SDN 01 Popayato termasuk dalam kategori baik. Hal ini dapat dilihat dari persentase yang diperoleh yaitu 70,17\%. Persentase kompetensi guru dalam mencantumkan aspek identitas mata pelajaran mencapai $84,38 \%$, Persentase kompetensi guru dalam mencantumkan komponen standar kompetensi $81,25 \%$, Persentase kompetensi guru dalam mencantumkan komponen kompetensi dasar 75\%. Persentase kompetensi guru dalam mencantumkan komponen indikator $81,25 \%$. Persentase kompetensi guru dalam mencantumkan komponen tujuan pembelajaran $75 \%$. Persentase kompetensi guru dalam mencantumkan komponen materi pembelajaran $62,50 \%$. Persentase kompetensi guru dalam mencantumkan komponen alokasi waktu 56,25\%. Persentase kompetensi guru dalam mencantumkan komponen metode pembelajaran 59,38\%. Persentase kompetensi guru dalam mencantumkan komponen langkah-langkah kegiatan pembelajaran 59,38\%. Persentase kompetensi guru dalam mencantumkan komponen sumber belajar 75\% persentase kompetensi guru dalam mencantumkan komponen penilaian (soal, pedoman penskoran, kunci jawaban) $62,50 \%$.

Berdasarkan data yang diperoleh diketahui bahwa kompetensi guru secara kualitas dan kuantitas mengalami peningkatan, meskipun demikian, secara keseluruhan dapat dikatakan tindakan pada siklus I belum berhasil karena belum sesuai dengan indikator keberhasilan yang ditetapkan. oleh karena itu, diperlukan adanya tindakan lebih lanjut dalam upaya meningkatkan kompetensi guru dalam menyusun RPP

\section{Siklus II}

Sama halnya dengan siklus pertama terdiri dari empat tahap yakni:(a) Perencanaan (Planning) (1) Membuat lembar wawancara,(2) Membuat 


$\begin{array}{ll}\text { Volume } & : 04 \\ \text { Nomor } & : 02 \\ \text { Bulan } & : \text { Mei } \\ \text { Tahun } & : 2018 \\ \text { http } & : \text { //ejurnal.pps.ung.ac.id/index.php/AKSARA/index }\end{array}$

format/instrumen penilaian RPP,(3) Membuat format Pelaksanaan Bimbingan Berkelanjutan rekapitulasi hasil penyusunan RPP siklus II , (4) Membuat format rekapitulasi hasil penyusunan RPP dari siklus ke siklus. (b) Pelaksanaan (Acting) : Peneliti memberikan bimbingan secara berkelanjutan berlangsung secara terus menerus untuk dapat mengembangkan potensi guru secara optimal dan mendapat kemajuan dalam menyusun RPP. (c) Observasi dilaksanakan terhadap delapan orang guru.

Berdasarkan penelitian yang dilakukan diperoleh data mengenai kompetensi guru dalam menyusun RPP dengan komponen : (a) Identitas mata pelajaran (b) standar kompetensi (c) kompetensi dasar (d)indikator pencapaian kompetensi (e) tujuan pembelajaran (f) materi pembelajaran (g) alokasi waktu (h) metode pembelajaran (i) langkah-langkah kegiatan pembelajaran (j) sumber belajar (k) penilaian (soal, pedoman penskoran, kunci jawaban) berikut ini.

Tabel 3

Data Kompetensi Guru Dalam Menyusun RPP di SDN 01 Popayato Siklus II

\begin{tabular}{|l|l|c|c|c|c|c|c|c|c|c|c|c|c|}
\hline \multirow{2}{*}{ No } & \multicolumn{1}{|c|}{ Nama } & \multicolumn{10}{|c|}{ Jumlah } \\
\cline { 3 - 12 } & & A & B & C & D & E & F & G & H & I & J & K & \\
\hline 1 & Maryam Onu, S.Pd & 4 & 4 & 4 & 4 & 3 & 3 & 4 & 4 & 3 & 4 & 4 & 41 \\
\hline 2 & Yowan Umar, S.Pd & 3 & 3 & 3 & 3 & 4 & 4 & 3 & 3 & 3 & 4 & 3 & 36 \\
\hline 3 & I Made Bawa, S.Pd & 4 & 4 & 3 & 3 & 4 & 3 & 3 & 3 & 4 & 3 & 3 & 37 \\
\hline 4 & $\begin{array}{l}\text { Sri Yiyin Otoluwa, } \\
\text { S.Pd }\end{array}$ & 4 & 3 & 3 & 4 & 4 & 3 & 3 & 3 & 3 & 4 & 4 & \\
\hline 5 & Supratni & 3 & 3 & 4 & 3 & 3 & 4 & 4 & 4 & 3 & 3 & 3 & 37 \\
\hline 6 & Rita Godang & 4 & 4 & 3 & 4 & 4 & 3 & 4 & 4 & 3 & 3 & 3 & 39 \\
\hline 7 & Isnah H Rumampuk & 4 & 4 & 3 & 3 & 3 & 3 & 3 & 3 & 3 & 4 & 3 & 37 \\
\hline 8 & Ahrudin A Otoluwa & 3 & 3 & 4 & 4 & 3 & 3 & 4 & 4 & 3 & 3 & 4 & 38 \\
\hline Jumlah & \multicolumn{10}{|c|}{} \\
\hline
\end{tabular}

Keterangan :

$\mathrm{A}=$ Komponen identitas mata pelajaran

$\mathrm{B}=$ Komponen standar kompetensi

$\mathrm{C}=$ Komponen kompotensi dasar

$\mathrm{D}=$ Komponen indikator

$\mathrm{E}=$ Komponen tujuan pembelajaran

$\mathrm{F}=$ Komponen alokasi waktu

$\mathrm{G}=$ Komponen materi ajar

$\mathrm{H}=$ Komponen metode pembelajaran

$\mathrm{I}=$ Komponen langkah - langkah kegaiatan pembelajaran

$\mathrm{J}=$ Komponen Sumber Belajar

$\mathrm{K}=$ Komponen Penilaian

Ketercapaian :

$85 \%-100 \%=$ sangat baik 


$\begin{array}{ll}\text { Volume } & : 04 \\ \text { Nomor } & : 02 \\ \text { Bulan } & : \text { Mei } \\ \text { Tahun } & : 2018 \\ \text { http } & : / / \text { jurnal.pps.ung.ac.id/index.php/AKSARA/index }\end{array}$

$70 \%-84 \%=$ baik

$55 \%-69 \%=$ cukup

Berdasarkan tabel 4.3 di atas menunjukkan bahwadari segi kualitas kompetensi guru di SDN 01 Popayato termasuk dalam kategori sangat baik. Hal ini dapat dilihat dari persentase yang diperoleh yaitu $86,08 \%$. Persentase kompetensi guru dalam mencantumkan aspek identitas mata pelajaran mencapai 90,63\%, Persentase kompetensi guru dalam mencantumkan komponen standar kompetensi $87,50 \%$, Persentase kompetensi guru dalam mencantumkan komponen kompetensi dasar $84,38 \%$. Persentase kompetensi guru dalam mencantumkan komponen indikator $87,50 \%$. Persentase kompetensi guru dalam mencantumkan komponen tujuan pembelajaran $87,50 \%$. Persentase kompetensi guru dalam mencantumkan komponen materi pembelajaran 81,25\%. Persentase kompetensi guru dalam mencantumkan komponen alokasi waktu $87,50 \%$. Persentase kompetensi guru dalam mencantumkan komponen metode pembelajaran 87,50\%. Persentase kompetensi guru dalam mencantumkan komponen langkah-langkah kegiatan pembelajaran $81,25 \%$. Persentase kompetensi guru dalam mencantumkan komponen sumber belajar 87,50\% persentase kompetensi guru dalam mencantumkan komponen penilaian (soal, pedoman penskoran, kunci jawaban) $84,38 \%$.

\section{Pembahasan}

Penelitian Tindakan Sekolah dilaksanakan di SDN 01 Popayato Kabupaten Pohuwato terdapat 8 orang guru yang memerlukan pembimbingan dan dilaksanakan dalam dua siklus. Keadaan guru tersebut menunjukkan sikap yang baik dan termotivasi dalam menyusun RPP dengan lengkap. Hal ini peneliti ketahui dari hasil pengamatan pada saat melakukan wawancara dan bimbingan penyusunan RPP. Selanjutnya dilihat dari kompetensi guru dalam menyusun RPP, terjadi peningkatan dari siklus ke siklus.

a. Komponen Identitas Mata Pelajaran

Pada siklus pertama semua guru (delapan orang) mencantumkan identitas mata pelajaran dalam RPP-nya (melengkapi RPP-nya dengan identitas mata pelajaran). Jika dipersentasekan siklus I mencapai $84,38 \%$ dan meningkat menjadi 90,63\%.pada siklus II

b. Komponen Standar Kompetensi

Pada siklus pertama semua guru (delapan orang) mencantumkan standar kompetensi dalam RPP-nya (melengkapi RPP-nya dengan standar kompetensi). Jika dipersentasekan $81,25 \%$ pada siklus I dan meningkat menjadi $87,50 \%$ pada siklus II

c. Komponen Kompetensi Dasar

Pada siklus pertama semua guru (delapan orang) mencantumkan kompetensi dasar dalam RPP-nya (melengkapi RPP-nya dengan kompetensi dasar). Jika dipersentasekan, $75 \%$ pada siklus I dan meningkat menjadi $84,38 \%$ pada siklus II. d. Komponen Indikator Pencapaian Kompetensi 


$\begin{array}{ll}\text { Volume } & : 04 \\ \text { Nomor } & : 02 \\ \text { Bulan } & : \text { Mei } \\ \text { Tahun } & : 2018 \\ \text { http } & : / / \text { jurnal.pps.ung.ac.id/index.php/AKSARA/index }\end{array}$

Pada siklus pertama semua guru (delapan orang) mencantumkan kompetensi indikator dalam RPP-nya (melengkapi RPP-nya dengan indikator). Jika dipersentasekan, $81,25 \%$ pada siklus I dan meningkat menjadi $87,50 \%$ pada siklus II.

e. Komponen Tujuan Pembelajaran

Pada siklus pertama semua guru (delapan orang) mencantumkan tujuan pembelajaran dalam RPP-nya (melengkapi RPP-nya dengan tujuan pembelajaran). Jika dipersentasekan, $75 \%$ pada siklus I dan meningkat menjadi $87,50 \%$ pada siklus II.

f. Komponen Materi Ajar

Pada siklus pertama semua guru (delapan orang) mencantumkan materi ajar dalam RPP-nya (melengkapi RPP-nya dengan materi ajar). Jika dipersentasekan 62,50\% pada siklus I dan meningkat menjadi $81,25 \%$ pada siklus II.

g. Komponen Alokasi Waktu

Pada siklus pertama semua guru (delapan orang) mencantumkan alokasi waktu dalam RPP-nya (melengkapi RPP-nya dengan alokasi waktu). Jika dipersentasekan, $56,25 \%$ pada siklus I dan meningkat menjadi $87,50 \%$ pada siklus II.

h. Komponen Metode Pembelajaran

Pada siklus pertama semua guru (delapan orang) mencantumkan metode pembelajaran dalam RPP-nya (melengkapi RPP-nya dengan metode pembelajaran). Jika dipersentasekan, 75\% pada siklus I dan meningkat menjadi 59,36\% pada siklus II.

i. Komponen Langkah-Langkah Kegiatan Pembelajaran

Pada siklus pertama semua guru (delapan orang) mencantumkan tlangkah - langkah pembelajaran dalam RPP-nya (melengkapi RPP-nya dengan langkah - langkah pembelajaran). Jika dipersentasekan, 59,38\% pada siklus I dan meningkat menjadi $81,25 \%$ pada siklus II.

j. Komponen Sumber Belajar

Pada siklus pertama semua guru (delapan orang) mencantumkan sumber belajar dalam RPP-nya (melengkapi RPP-nya dengan sumber belajar). Jika dipersentasekan, $75 \%$ pada siklus I dan meningkat menjadi $87,50 \%$ pada siklus II. k. Komponen Penilaian Hasil Belajar

Pada siklus pertama semua guru (delapan orang) mencantumkan penilaian hasil belajar dalam RPP-nya (melengkapi RPP-nya dengan penilaian hasil belajar). Jika dipersentasekan, $62,50 \%$ pada siklus I dan meningkat menjadi $84,38 \%$ pada siklus II.

Berdasarkan pembahasan di atas terjadi peningkatan kompetensi guru dalam menyusun RPP. Pada siklus I nilai rata-rata komponen RPP 70,17\% pada siklus II nilai rata-rata komponen RPP 86,08\%, terjadi peningkatan $15,91 \%$.

\section{Kesimpulan}

Bimbingan berkelanjutan dapat meningkatkan motivasi guru dalam menyusun RPP dengan lengkap. Guru menunjukkan keseriusan dalam memahami 


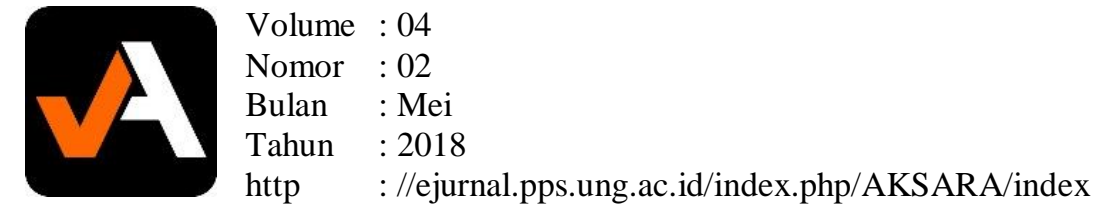

dan menyusun RPP apalagi setelah mendapatkan bimbingan pengembangan/penyusunan RPP dari peneliti. Informasi ini peneliti peroleh dari hasil pengamatan pada saat mengadakan wawancara dan bimbingan pengembangan/penyusunan RPP kepada para guru.

Bimbingan berkelanjutan dapat meningkatkan kompetensi guru dalam menyusun RPP. Hal itu dapat dibuktikan dari hasil observasi /pengamatan yang memperlihatkan bahwa terjadi peningkatan kompetensi guru dalam menyusun RPP dari siklus I ke siklus II yaitu dari data awal $55,68 \%$ menjadi $70,17 \%$ pada siklus I, dan meningkat menjadi $86,08 \%$ pada siklus II.

\section{DAFTAR PUSTAKA}

Daradjat, Zakiyah. 1980. Kepribadian Guru. Jakarta: Bulan Bintang.

Depdiknas. 2003. UU RI No. 20 Tahun 2003 tentang Sistem Pendidikan Nasional. Jakarta: Depdiknas.

2004. Standar Kompetensi Guru Sekolah Dasar. Jakarta: Depdiknas.

2005. UU RI No. 14 Tahun 2005 tentang Guru dan Dosen. Jakarta: Depdiknas.

2005. Standar Nasional Pendidikan. Jakarta: Depdiknas.

2007. Permendiknas RI No. 41 Tahun 2007a tentang Standar Proses. Jakarta: Depdiknas.

2007. Permendiknas RI No. 12 Tahun 2007b tentang Standar Pengawas Sekolah/Madrasah. Jakarata: Depdiknas.

2008. Alat Penilaian Kemampuan Guru. Jakarta: Depdiknas.

2009. Petunjuk Teknis Pembuatan Laporan Penelitian Tindakan Sekolah Sebagai Karya Tulis Ilmiah Dalam Kegiatan Pengembangan Profesi Pengawas Sekolah. Jakarta.

Imron, Ali. 2000. Pembinaan Guru Di Indonesia. Malang: Pustaka Jaya.

Kemendiknas. 2010. Penelitian Tindakan Sekolah. Jakarta.

2010. Supervisi Akademik. Jakarta.

Pidarta, Made . 1992. Pemikiran Tentang Supervisi Pendidikan. Jakarta: Bumi Aksara. 
Sudjana, Nana. 2009. Standar Kompetensi Pengawas Dimensi dan Indikator. Jakarta : Binamitra Publishing.

Suparlan. 2005. Menjadi Guru Efektif. Yogyakarta: Hikayat Publishing. 2006. Guru Sebagai Profesi. Yogyakarta: Hikayat Publishing.

Walgito, Bimo. 1986. Bimbingan Dan Penyuluhan Di Sekolah. Yogyakarta : Andi Offset 